\title{
Kirjallisuus musiikissa ja musiikki kirjallisuudessa
}

\section{Siru Kainulainen, Liisa Steinby \& Susanna Välimäki (toim.): Kirjallisuuden ja musiikin leikkauspintoja. Helsinki: SKS 2018, 429 S.}

Musiikin ja kirjallisuuden suhde on kiehtova mutta vaikeasti tavoitettava ja verraten vähän tutkittu aihe. Musiikki on kuitenkin aina inspiroinut kirjailijoita, samoin kuin kirjallisuus muusikoita. Taiteenlajit onkin nähty sisaruksina, joita alun perin ei ole voinut edes erottaa toisistaan. Muistelmateoksessaan Ihmisen toivo Nadežda Mandelštam kuvaa puolisonsa Osipin runojen syntyprosessia:

Runot saavatalkunsa näin [--]:aluksi on muotoutumaton ja sitten täsmällinen mutta vielä sanaton musikaalinen teema. Satuin usein näkemään, miten OM [Osip Mandelštam] yritti vapautua melodiasta, hätistää sen pois [--]. Hän ravisteli päätään aivan kuin melodian olisi voinut ravistaa ulos niin kuin kylvyssä korvaan menneen veden. Mutta mikään ei tukahduttanut sitä - ei melu eikä radio eikä samasta huoneesta kuuluva puhe. [--] Jonakin hetkenä musikaalisen teeman ylitse alkoi tunkea sanoja, ja silloin huulet alkoivat liikahdella. Säveltäjän ja runoilijan työssä on luultavasti jotain yhteistä, ja sanojen ilmaantuminen on se kriittinen hetki, joka erottaa nämä kaksi luomisen muotoa toisistaan. $(1972,73$.

Lyriikka on kirjallisuuden lajeista ilmeisimmin sukua musiikille ja sidoksissa siihen. Johdannossaan Kirjallisuuden ja musiikin leikkauspintoja -teoksen toimittajat muistuttavatkin runouden ja musiikin eriytymättömyydestä kulttuurin varhaisvaiheessa. Toisaalta myös proosasta ja draamasta löytyy musiikille ominaisia elementtejä erityisesti niiden rakenteen tasolla. Kokoomateoksen teoreettinen tausta ammentaa taiteidenvälisyyden tutkimuksesta ja intermediaalisuudesta eli eri medioiden välisistä kytköksistä ja vuorovaikutuksesta. Tieteidenvälisyyttä korostaa se, että kirjoittajina on sekä kirjallisuus- että musiikkitieteilijöitä. Kirjan lähtökohta onkin hedelmällinen: tavoitteena ei ole ollut luoda kattavaa esitystä kirjallisuuden ja musiikin suhteesta, vaan tarkastella niiden risteävyyttä ja vuorovaikutusta, jotka tulevat esiin edellä mainituissa leikkauspinnoissa.

Teoksen aikaskaala ulottuu romantiikan ajoista nykypäivään. Se käsittelee eri näkökulmista kirjallisuuden vaikutusta musiikkiin ja musiikin vaikutusta kirjallisuuteen, niiden yhteisiä piirteitä ja eroavaisuuksia, joita ei ole helppo tavoittaa, koska musiikki- ja kirjallisuustieteissä käytetään osin samoja käsitteitä, joskaan ei aivan samassa merkityksessä. Taiteenlajeja yhdistäviä tekijöitä 
ovat joka tapauksessa rytmi ja ääni sekä ajallisuus ja tarinallisuus. Toisaalta kirjallisuudesta puhuttaessa äänteellisyys jää usein vähemmälle huomiolle, ja musiikin semanttiset ainekset ovat sanataidetta vaikeammin tavoitettavissa.

Teoksen kirjoituksista nousee esiin erityisesti proosan musiikillisuus. Liisa Steinbyn artikkelin aiheena on romaanin musiikinomainen rakentuminen Friedrich Schlegelin romaaniteoriassa, Thomas Mannin Tohtori Faustuksessa sekä Milan Kunderan romaaneissa. Schlegel kirjoittaa romaanista todellisena runoutena, joka musiikillisuudessaan rikkoo klassisen romaanin kronologisen esitystavan ja pyrkii sisällyttämään koko modernin todellisuuden itseensä. Tästä näkökulmasta sekä Mannin että Kunderan romaaneja voidaan lähestyä musiikillisina kompositioina, joiden polyfonia syntyy itsenäisten äänien tai juonteiden limittyessä toisiinsa. Polyfoniaa käsittelee myös Krystszov Majer eritellessään Vladimir Nabokovin varhaista novellia Bachmann, jossa kolme toisiaan takaa ajavaa ääntä muodostavat vastakkainasetteluineen ja purkautumisineen fuugamaisen kokonaisuuden.

Romaanin musiikillista rakentumista tarkastelevat kirjoituksissaan myös Viola Parente-Čapkova, Matti Ahvenus ja Lotta Kähkönen. Parente-Čapkova lähestyy tekstissään L. Onervan Mirdja -romaania "musiikillisen mimesiksen" käsitteen kautta: romaanin rakenteet muodostavat sekasointuisen moniäänisyyden, joka ilmentää aikansa fin de siècle -estetiikkaa. Ahvenuksen artikkelin aiheena on Toni Morrisonin romaani Jazz, ja Kähkönen tarkastelee Jackie Kayn elämäkertaa blues-laulaja Bessie Smithistä. Morrisonin jazz-improvisaatio ja Kayn blueskerronta määrittävät kyseisten teosten muotoa: musiikki läpäisee ne sekä tematiikan että rakenteen tasoilla.

Minulle erityisen avartavia olivat musiikkitieteilijöiden kirjoitukset. Musiikkia taiteenlajina leimaa ruumillisuus, sen kokeminen oman kehon kautta. Vaikka kirjallisuus on tallennettu äänettömiksi merkeiksi, lukukokemus voi olla samalla tavoin fyysinen kuin silloin, kun muusikon tekemästä nuottien tulkinnasta syntyy musiikkielämys. Laura Wahlfors käsittelee artikkelissaan E. T. A. Hoffmannin romaaneja Robert Schumannin Kreisleriana -soolopianosarjan taustateksteinä. Näkökulma on pianistin, ja erityisen mielenkiintoista on lukea kirjallisten intertekstien vaikutuksesta itse musiikkiesityksen muotoutumiseen. Yrjö Heinonen taas käsittelee Felix Mendelssohnin Kesäyön unelma -alkusoiton sonaattimaista, kertovaa rakennetta William Shakespearen näytelmän adaptaationa. Susanna Välimäki analysoi omassa artikkelissaan, miten rikosromaanien taustalla soiva ja päähenkilöiden kuuntelema musiikki luo tarinaan syvempiä merkityksiä. Kaikki kolme kirjoitusta valaisevat musiikkitiedettä tarkemmin tuntemattomalle oivallisesti musiikin semantiikkaa, joka yltää sanallisen ilmaisun ulkopuolelle.

Musiikkia runoudessa käsitellään erityisesti kolmessa kokoelman kirjoituksessa. Siru Kainulainen tarkastelee suomalaisen nykyrunouden äänteellisyyttä sekä musiikillisia keinoja ja rakenteita, jotka helposti jäävät kielellisen seman- 
tiikan varjoon. Vaikka modernismi luopui perinteisistä mitoista, ne ovat erotettavissa nykyrunoudenkin taustalla. Inka Rantakallio analysoi suomenkielistä rap-lyriikkaa ja nostaa esiin rap-puheen flown, joka rakentaa esityksen rytmien ja riimien varaan. Lea Rojolan kirjoitus taas käsittelee Nils-Aslak Valkeapään runoutta, jonka taustalla vaikuttaa joiku saamelaisten yhteisöllisen olemisen muotona.

John Richardson tuo teokseen mukaan elokuvan maailman musiikkia audiovisuaalisessa mediassa käsittelevässä artikkelissaan. Erityisesti hän painottaa elokuvapuheen musiikillistumista, jossa puheen rytmi, tempo, korkeus ja äänensävyt nousevat jopa pääosaan. Musiikillisuus syntyy tällöin kielen semanttiseen funktioon palautumattomista puheen tekijöistä.

Kuten kirjan takakannessa todetaan, kirjallisuuden ja musiikin rajamaastoon sijoittuvia ilmiöitä tarkastelevana teos on Suomessa ensimmäinen laatuaan. Kaiken kaikkiaan kirjallisuus- ja musiikkitieteilijöiden yhteinen projekti avaa innostavia näkökulmia, joista muodostuu kiehtova sana- ja säveltaiteeseen luotujen kurkistusikkunoiden kollaasi.

Jussi Hyvärinen

\section{Lähteet}

Mandelštam, Nadežda 1972. Ihmisen toivo. Suom. Esa Adrian. Helsinki: Tammi. 